\title{
Use of ELISA to monitor bacterial kidney disease in naturally spawning chinook salmon
}

\author{
Glenda O'Connor ${ }^{1}$, Timothy L. Hoffnagle ${ }^{2, *}$ \\ ${ }^{1}$ La Grande Fish Health Laboratory, Oregon Department of Fish and Wildlife, 219 Badgley Hall, Eastern Oregon University, \\ La Grande, Oregon 97850, USA \\ ${ }^{2}$ Northeast Oregon Fish Research, Oregon Department of Fish and Wildlife, 203 Badgley Hall, Eastern Oregon University, \\ La Grande, Oregon 97850, USA
}

\begin{abstract}
Bacterial kidney disease (BKD) caused by Renibacterium salmoninarum (Rs) is a serious problem among Pacific Northwest salmon hatcheries and has raised concerns that salmon reared in hatcheries may spread BKD to natural populations. In order to monitor the potential spread of this disease to salmon spawning in nature, a method must be available to collect and analyze tissues from naturally spawning salmon. Kidney tissue analyzed by enzyme-linked immunosorbent assay (ELISA) is the standard method to detect the presence of Rs in salmon sampled in hatcheries. In this study, we tested the validity of using ELISA on kidney tissue collected from intact carcasses recovered on the spawning grounds to monitor BKD in naturally spawning populations by comparing ELISA optical density (OD) values from kidney tissue that was subjected to conditions that simulated decomposition in a carcass and collection during a spawning ground survey with samples freshly collected from salmon at a hatchery. Mean ELISA OD levels were 1.060 for the samples prepared by the normal preparation and 1.115 for samples prepared by simulating spawning ground survey collection. There was no significant difference in mean ELISA OD between the 2 sample preparations and the relationship did not significantly differ from 1:1 (slope $=0.946$ ). This demonstrates that BKD prevalence in natural populations can be monitored using ELISA conducted on samples from intact carcasses recovered on spawning ground surveys. This will be an important tool for monitoring the effect of hatchery supplementation on naturally spawning salmon populations.
\end{abstract}

KEY WORDS: Bacterial kidney disease - BKD · Enzyme-linked immunosorbent assay · ELISA • Chinook salmon $\cdot$ Spawning ground survey $\cdot$ Hatchery

Resale or republication not permitted without written consent of the publisher

\section{INTRODUCTION}

Bacterial kidney disease (BKD) caused by Renibacterium salmoninarum (Rs) is a widespread and serious concern among Pacific Northwest salmon hatcheries (Fryer \& Lannan 1993, Maule et al. 1996). This Gram-positive organism is difficult to treat with antibiotics and can persist through the entire lifetime of a fish (Rohovec 1991). Once established in a population, the organism can be transmitted from fish to fish (horizontal transmission, McKibben \& Pascho 1999) and adult females that are infected with Rs can transmit the organism to their progeny (vertical transmission, Evelyn et al. 1986). Enzyme-linked immunosorbent assay (ELISA) is the standard serodi- agnostic method used to detect the presence of Rs in salmon (Pascho et al. 1991). The ELISA detects the presence and amount of the Rs p57 antigen, or antigen $\mathrm{F}$, a $57 \mathrm{kDa}$ protein and the chief soluble antigen produced by Rs (Wiens \& Kaattari 1989). It plays a role in the virulence of this pathogen and is found both on the surface of the bacterial cell and in a soluble extracellular form (Getchell et al. 1985, Turaga et al. 1987, Bruno 1988). The BKD ELISA is used at many hatcheries to screen adult salmon for BKD, allowing culling of eggs from Rs-infected females or segregation of their offspring, strategies which have proven effective in reducing BKD in hatchery populations by reducing vertical transmission (Pascho et al. 1991). 
Hatcheries play an important part in the restoration and supplementation of threatened and endangered stocks of Pacific salmon Oncorhynchus spp. (Brannon et al. 2004). However, there are also concerns about hatcheries, including their potential to spread disease to natural populations (Hastein \& Lindstad 1991, Waples 1999). Chinook salmon O. tshawytscha in the Grande Ronde and Imnaha basins of northeast Oregon are listed as threatened under the Endangered Species Act (Federal Register, Volume 57, Number 78:1456314663) and hatchery programs were developed as early as 1982 to restore and supplement their populations (Carmichael \& Messmer 1995, Monzyk et al. 2007). In the Grande Ronde Basin, the populations declined to levels so low that a captive broodstock program was developed to prevent imminent extirpation (Hoffnagle et al. 2003). In the Grande Ronde Basin Spring Chinook Salmon Captive Broodstock Program, $\mathrm{BKD}$ is the largest source of mortality, causing up to $63 \%$ of the total loss during rearing (Hoffnagle et al. 2003, Oregon Department of Fish and Wildlife 2004, $2005,2006,2007)$. At the time of spawning, up to $75 \%$ of the females have indications of past or present Rs infection, as indicated by ELISA optical density (OD) levels $>0.400$.

Because Rs can be vertically transmitted (Evelyn et al. 1986), when BKD is prevalent in a hatchery broodstock, managers must decide whether to cull the eggs from positive females or to rear and release their offspring in the anticipation that at least some will survive and help restore the threatened populations. However, releasing offspring from females with a high ELISA OD and a high risk of Rs infection raises the concern of increasing the prevalence of Rs in natural populations. Any population being supplemented by a captive broodstock program is likely to be near extinction, and a primary goal is to conserve as much of the genetic diversity as possible. This may sometimes result in the release of offspring from females with high ELISA OD levels, despite the possibility that the females have transmitted the disease to at least some of their offspring and more juveniles may be subsequently infected horizontally. If returning adults produced by the captive broodstock program are allowed to spawn in nature, as is the case for the Grande Ronde Captive Broodstock Program, a method is needed to monitor the prevalence and incidence of BKD in naturally spawning adults and determine whether these hatchery origin salmon are spreading the disease to natural salmon. This type of monitoring program is equally important for any hatchery supplementation program where BKD is a concern (Waples 1999).

Beginning in 2000, kidney samples from pre-and post-spawning mortalities in the John Day River Basin were collected to test for Rs infection by ELISA sam- pling of dead, naturally spawning Chinook salmon (Wilson et al. 2002a,b). This practice has since expanded to include streams in the Grande Ronde Basin to monitor the effect, if any, of the release of captive broodstock offspring into nature.

When analyzing kidney samples from naturallyspawned carcasses, the length of time since the death of the fish and the manner in which the samples are handled prior to arrival at the laboratory may affect ELISA results. Consideration of these factors has led to speculation as to the validity of ELISA results obtained under such circumstances. Salmon carcasses found in streams are often degraded at the time of collection, stream-side collections are not ideal for sterile tissue collections, and sample contamination, during or prior to collection must be a concern. Therefore Oregon Department of Fish and Wildlife (ODFW) protocol for kidney collection is that (1) the carcass must be intact, with the abdominal cavity not open to the environment; (2) the organs remain distinct; and (3) the retroperitoneal membrane remains intact. To eliminate cross contamination, we use individual, pre-assembled, one-use sample collection kits.

The purpose of this study was to determine whether ELISA is a valid method for monitoring BKD prevalence in naturally spawning salmon and whether these results are comparable to those collected from freshly killed salmon. Specifically, this study compared ELISA OD levels between a tissue sample prepared by the standard method for hatchery monitoring (normal) versus a sample, from the same fish, subjected to an approximation of field conditions: a carcass laying in the stream for several days following death before being carried in a backpack for several hours after being collected (spawning ground survey). In this way, we could determine whether ELISA can be used on kidney samples collected from carcasses recovered on the spawning grounds to measure the BKD infection level of salmon in nature.

\section{MATERIALS AND METHODS}

Kidney tissue samples were collected from 25 mature Chinook salmon males during spawning of the Grande Ronde Basin Spring Chinook Salmon Captive Broodstock Program in September 2005 at Bonneville Fish Hatchery. These fish were used because of the high likelihood of obtaining samples with a wide range of ELISA OD levels. Duplicate adjacent kidney samples were collected from each salmon and placed in separate Whirl-Pak bags. The samples were frozen $\left(-5^{\circ} \mathrm{C}\right)$ for 24 to $48 \mathrm{~h}$ and transported, on ice, to the Oregon Department of Fish and Wildlife La Grande Fish Health Laboratory, where 
they were stored at $-28^{\circ} \mathrm{C}\left( \pm 1.0^{\circ} \mathrm{C}\right)$. Tissue sample size ranged from 0.56 to $2.57 \mathrm{~g}$.

On 11 to 13 October 2005, one of the duplicate samples from each male was exposed to the likely temperature regime to which a kidney sample would be subjected when decomposing in a northeast Oregon stream and collected during a spawning ground survey. This sample was placed in a $16^{\circ} \mathrm{C}$ incubator for $48 \mathrm{~h}$ to simulate the maximum temperature to which a salmon carcass in northeast Oregon is likely to be exposed prior to recovery: 1 to $4 \mathrm{~d}$ in a stream with diel temperature fluctuating between 6 and $20^{\circ} \mathrm{C}$. The samples were then removed from the incubator and placed in a drying oven at $27.8^{\circ} \mathrm{C}\left( \pm 1.0^{\circ} \mathrm{C}\right)$ for $6 \mathrm{~h}$ to simulate the time that a sample might spend in a backpack while the survey was being conducted. Then the samples were again stored at $-28^{\circ} \mathrm{C}\left( \pm 1.0^{\circ} \mathrm{C}\right)$ until they could be processed and analyzed by ELISA, as they would be following spawning ground survey collection. Samples collected for standard hatchery monitoring remained frozen until processing and analysis. From this point, all samples (normal and spawning ground survey simulation) were treated identically.

On 25 October 2005, all samples were processed using the standard protocol for kidney ELISA preparations. PBS-Tween 20 was added to each sample bag to create a 1:3 tissue to diluent ratio. This mixture was crushed with a marble rolling pin and placed in a Seward Stomacher 80 for $1 \mathrm{~min}$ to disrupt tissue and facilitate antigen release into the supernatant. The sample, $1.8 \mathrm{ml}( \pm 0.2 \mathrm{ml})$, was then poured into a labeled $2.0 \mathrm{ml}$ screw cap vial, incubated in a $100^{\circ} \mathrm{C}$ water bath for $10 \mathrm{~min}$., cooled to room temperature, centrifuged for $4 \mathrm{~min}$. at $10000 \times g$, and returned to the freezer.

The ELISA was run on 28 October 2005 for 7 of the 25 samples and on 9 November for the remaining 18 samples. Two replicate samples for each tissue sample were assayed and the paired (spawning ground survey simulation and normal) samples were assayed on the same day in adjacent wells. Each assay included a buffer control (PBS-Tween 20) and a 1:3 dilution negative kidney tissue control for both runs. Mean replicate values for buffer control (0.056 and 0.054) and for the negative tissue control (0.062 and 0.062$)$ were within typical assay ranges and variation between replicates within samples was also low. Mean OD difference between sample replicates was $0.030(2.7 \%$ of the mean ELISA OD value) and the mean variance was 0.0015 .

LaGrande Fish Health Services (ODFW) has conducted the ELISA since 1992, using protocols developed by Pascho el al. (1991). Non-kit-style reagents, as well as antibodies, are supplied by Kirkegaard \& Perry Laboratories. The antibodies and standards used in the
ELISA are prepared in-house, aliquoted into singleuse cryovials and stored in $\mathrm{a}-85^{\circ} \mathrm{C}$ freezer. For continuity, significant amounts are prepared for approximately 2 yr of ELISA runs.

Differences in mean ELISA OD levels were compared between the normal and spawning ground survey preparations by paired $t$-test and the relationship between the 2 sample preparations was examined by regression (Sokal \& Rohlf 1995). Additionally, a $t$-test was used to determine whether the slope of the relationship between the normal and spawning ground survey preparations differed from 1 (Neter et al. 1990). Differences between means were considered to be significant at $\alpha<0.05$.

\section{RESULTS}

Mean ELISA OD was 1.060 for the samples prepared by the normal preparation method and 1.115 for samples prepared by simulating spawning ground survey

Table 1. ELISA OD levels for 25 paired Chinook salmon kidney samples prepared by the normal preparation or by simulating collection from carcasses on spawning ground surveys (SGS) and the differences in levels between the 2 methods

\begin{tabular}{|lcccc|}
\hline $\begin{array}{l}\text { Fish } \\
\text { number }\end{array}$ & $\begin{array}{c}\text { Spawn date } \\
\text { (Sep 2005) }\end{array}$ & Normal & SGS & $\begin{array}{c}\text { Difference } \\
\text { (Normal - SGS) }\end{array}$ \\
\hline CC 05 & 7 & 0.088 & 0.085 & 0.003 \\
CC 10 & 7 & 1.501 & 1.546 & 0.045 \\
CC 11 & 7 & 1.856 & 2.237 & 0.381 \\
GR 08 & 14 & 0.137 & 0.189 & 0.052 \\
GR 24 & 14 & 1.911 & 1.906 & 0.005 \\
LR 02 & 14 & 1.699 & 1.535 & 0.164 \\
CC 19 & 14 & 0.073 & 0.105 & 0.032 \\
CC 24 & 14 & 1.943 & 1.219 & 0.725 \\
CC 23 & 14 & 0.260 & 0.499 & 0.239 \\
CC 25 & 14 & 2.046 & 2.000 & 0.046 \\
CC 30 & 14 & 1.930 & 1.921 & 0.009 \\
CC 32 & 20 & 0.083 & 0.103 & 0.020 \\
CC 35 & 20 & 0.189 & 0.342 & 0.154 \\
CC 39 & 20 & 2.003 & 2.143 & 0.140 \\
CC 41 & 20 & 2.017 & 2.159 & 0.142 \\
CC 48 & 20 & 1.583 & 1.508 & 0.075 \\
CC 51 & 20 & 0.955 & 1.800 & 0.845 \\
CC 65 & 20 & 0.146 & 0.179 & 0.033 \\
CC 71 & 20 & 0.078 & 0.073 & 0.005 \\
CC 76 & 20 & 2.369 & 2.525 & 0.157 \\
CC 78 & 20 & 2.184 & 2.293 & 0.109 \\
CC 79 & 20 & 1.216 & 1.266 & 0.051 \\
LR 31 & 27 & 0.076 & 0.072 & 0.004 \\
LR 36 & 27 & 0.098 & 0.091 & 0.007 \\
LR 64 & 27 & 0.067 & 0.068 & 0.001 \\
Mean & & 1.0603 & 1.1146 & 0.0543 \\
SD & & 0.8982 & 0.9127 & 0.2485 \\
Min. & & 0.067 & 0.068 & 0.001 \\
Max. & & 2.369 & 2.525 & 0.845 \\
& & & & \\
\hline
\end{tabular}




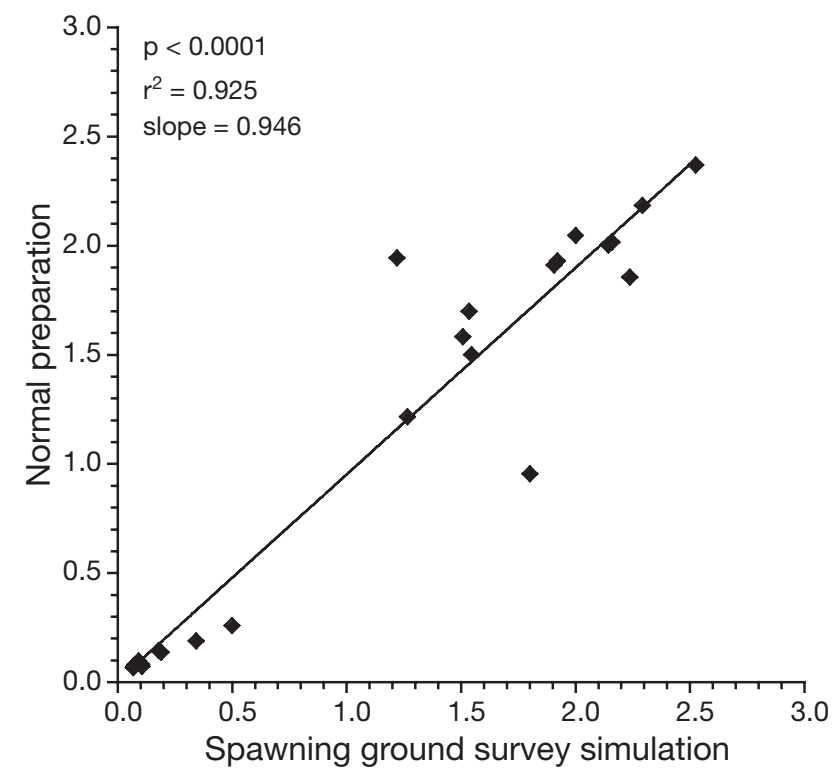

Fig. 1. Relationship between ELISA OD values for 25 paired Chinook salmon kidney samples prepared by the normal preparation and those prepared by simulating collection from carcasses on spawning ground surveys

collection (Table 1). There was no significant difference in mean ELISA OD between the 2 sample preparations $(p=0.8311)$ and the relationship between them was highly significant $\left(\mathrm{p}<0.0001, \mathrm{r}^{2}=0.925\right.$, slope $=$ 0.946) (Fig. 1). Although the calculated slopes of the lines reflecting the relationship between the normal and spawning ground survey preparations did not equal 1, this relationship did not significantly differ from a 1:1 relationship $(p=0.3509)$.

\section{DISCUSSION}

Our results demonstrate that kidney tissue collected from intact carcasses on spawning ground surveys and analyzed by ELISA can be reliably used to monitor BKD prevalence in natural populations. Also, kidney tissue samples properly collected under field conditions can be directly compared with samples collected from freshly killed salmon. However, there are 2 concerns that might affect ELISA results on tissues collected from decomposing salmon carcasses.

First, kidney samples collected from decomposing carcasses during spawning ground surveys may be contaminated by other (non-Rs) microorganisms and/or their products present in the environment before and/or during sample collection, which could affect the ELISA result. Gut bacteria may leak out and contaminate the kidney, external microorganisms may enter the carcass, and/or other microorganisms may flourish in the decomposing kidney and affect the ELISA. Contamination may also occur during sample collection due to unsterile collection tools. However, under the protocols outlined in the 'Introduction,' external bacteria should not be a problem, because we collect samples only from intact carcasses and use a new collection kit for each sample, and because the organs remain distinct, with the kidney isolated from leaked gut bacteria by the retroperitoneal membrane and deflated swim bladder. Although we found that the spawning ground simulation samples generally had a higher ELISA OD value (mean $=5.4 \%$ ) than the normal preparations, the difference was not significant and the regression slope (0.946) was found to not significantly differ from a slope of 1 . Additionally, while we had to simulate the decomposition process for this study (since it is not possible to both collect a fresh tissue sample from a fish and an aged sample from the same fish), the ODFW has been collecting kidney samples since 2004 from carcasses recovered during spawning ground surveys in streams from which adults are also collected for hatchery supplementation (ODFW unpubl. data). We found no difference in mean ELISA of samples collected from intact carcasses on spawning grounds versus samples collected during spawning at the hatchery. If contamination of carcasses caused a difference in ELISA OD values, we would have expected to see a difference in mean ELISA OD values between samples collected from these 2 sites. Given this information, we believe that any effect on ELISA results due to contamination is minor and does not significantly affect the accuracy of the assay or our ability to compare spawning ground survey results with those from hatcheries.

A second concern is that of degradation of the p57 antigen during the decomposition process. The p57 antigen appears to remain stable at elevated temperatures and we found no evidence of its degradation after $2 \mathrm{~d}$ of simulating carcass deterioration and subsequent sample collection, nor did we find a loss in the ability of ELISA to detect the antigen after such a period. Getchell et al. (1985) demonstrated that the p57 antigen was heat stable for $30 \mathrm{~min}$ at $100^{\circ} \mathrm{C}$ and Pascho et al. (1997) reported that the p57 antigen was still detectable by ELISA in hematopoietic tissues of rainbow trout Oncorhynchus mykiss that received an intraperitoneal bacterin injection and were held at $12^{\circ} \mathrm{C}$ for more than 3 mo. Conversely, Griffiths \& Lynch (1991) determined that p57 found in extracellular products is autolytic with regard to time and increased temperature, breaking down into several distinct degradation products over a $10 \mathrm{~h}$ incubation period at temperatures of 25 and $30^{\circ} \mathrm{C}$. However, these are temperatures well above those to which a carcass is likely to be exposed in a stream inhabited by salmon. It 
is possible that the higher ELISA OD values are caused by greater epitope availability through partial degradation of p57 at simulation temperature, the presence of compounds in decaying kidney tissue that absorb at $405 \mathrm{~nm}$, and/or fungal hyphae that can weakly bind the antibody. (L. Rhodes, NOAA Fisheries, pers. comm.). However, the spawning ground survey samples were higher than the normal preparation in 15 of the 25 samples. It would seem that if degradation was the cause, the spawning ground survey samples should be higher than the normal preparations more than $60 \%$ of the time. Again, it appears that a $5.4 \%$ difference in ELISA OD level, even if it is real and not a statistical anomaly, will not affect the use of ELISA for the purpose of monitoring BKD prevalence or comparing its prevalence between samples collected during spawning ground surveys and the more sterile conditions of a hatchery.

For 2 of 25 samples in this experiment (CC 24 and CC 51), there was a large difference in ELISA OD values between the normal preparation and spawning ground simulation (one higher in the spawning ground survey and the other in the normal preparation). When these 2 outlying samples are removed, the relationship improves further $\left(p<0.0001, r^{2}=0.986\right.$, slope $\left.=0.969\right)$. Both samples (CC 24 and CC 51) were in the clinical ELISA range ( $\geq 1$ ) (Fig. 1). Fish in this category are considered as having BKD and it is possible that an early stage granulomatous lesion was forming (Wiens \& Kaattari 1999). These lesions appear as whitish-grey nodules which vary in size and may have concentrated antibody-antigen complexes associated within them (C. Banner, ODFW, pers. comm.). Additionally, the distribution of Rs cells and p57 antigen within an infected kidney may not always be homogeneous and this uneven distribution is more pronounced in mature salmonids due to their larger kidneys (Meyers el al. 1993). Therefore it seems likely that, although they were taken proximally, one of these paired samples contained a forming lesion, which resulted in a higher concentration of the p57 antigen and a substantially higher ELISA OD value.

The ODFW began collecting kidney samples from Chinook salmon carcasses on spawning ground surveys in the John Day River Basin in 2000 and in the Grande Ronde Basin and the Imnaha River in 2004. Although there are no broodstock collections from the John Day Basin, ELISA OD levels have been similar to those found during spawning of hatchery broodstock from other streams in northeast Oregon (Wilson et al. 2002a,b). In the Grande Ronde Basin, there was no difference in mean ELISA OD levels between samples from the same populations collected during spawning ground surveys and those collected during broodstock spawning at Lookingglass Fish Hatchery (ODFW unpubl. data). These monitoring efforts and the present study show that BKD prevalence in natural populations can be effectively monitored using ELISA conducted on samples collected from intact carcasses. Additionally, fishery and hatchery managers can compare BKD prevalence in hatchery-spawned salmon with those spawning naturally. This will be an important tool for monitoring the effect of hatchery supplementation on naturally spawning salmon populations.

Acknowledgements. Thanks to Assistant Project Leader W. Wilson and crew (ODFW Northeast Region Fish Research, John Day), who initiated collection of kidney tissue from spawning ground surveys in 2000 in the John Day River Basin. Thanks also to S. Vendshus and D. Gibbs (ODFW Fish Health) for their help collecting and analyzing the samples, respectively. Drs. A. Amandi and C. Banner (ODFW Fish Health), Dr. L. Rhodes (NOAA Fisheries), R. Carmichael, D. Eddy, and Dr. J. Ruzycki (ODFW Fish Research) provided helpful comments on this manuscript. This project was supported by funds and facilities provided by the Bonneville Power Administration and the US Fish and Wildlife Service, Lower Snake River Compensation Plan.

\section{LITERATURE CITED}

Brannon EL, Amend DF, Cronin MA, Lannan JE and 7 others (2004) The controversy about salmon hatcheries. Fisheries 29:12-29

Bruno DW (1988) The relationship between auto-agglutination, cell surface hydrophobicity and virulence of the fish pathogen Renibacterium salmoninarum. FEMS Microbiol Lett 51:135-140

Carmichael RW, Messmer RT (1995) Status of supplementing chinook salmon natural production in the Imnaha River Basin. Am Fish Soc Symp 15:284-291

Evelyn TPT, Prosperi-Porta L, Ketcheson JE (1986) Experimental intra-ovum infection of salmonid eggs with Renibacterium salmoninarum and vertical transmission of the pathogen with such eggs despite their treatment with erythromycin. Dis Aquat Org 1:197-202

Fryer JL, Lannan CN (1993) The history and current status of Renibacterium salmoninarum, the causative agent of bacterial kidney disease in Pacific salmon. Fish Res 17:15-33

Getchell RG, Rohovec JS, Fryer JL (1985) Comparison of Renibacterium salmoninarum isolates by antigenic analysis. Fish Pathol 20:149-159

Griffiths SG, Lynch WH (1991) Instability of the major soluble antigen produced by Renibacterium salmoninarum. J Fish Dis 14:55-66

Hastein T, Lindstad T (1991) Diseases in wild and cultured salmon: possible interaction. Aquaculture 98:277-288

Hoffnagle TL, Carmichael RW, Noll WT (2003) Grande Ronde Basin spring Chinook salmon captive broodstock program, 1995-2002 project status report. Fish Research and Development Project, Oregon, Northeast Region, Oregon Department of Fish and Wildlife, La Grande, OR

Maule AG, Rondorf DW, Beeman J, Haner P (1996) Incidence of Renibacterium salmoninarum infections in juvenile hatchery spring chinook salmon in the Columbia and Snake rivers. J Aquat Anim Health 8:37-46

McKibben CL, Pascho RS (1999) Shedding of Renibacterium salmoninarum by infected Chinook salmon Oncorhynchus 
tshawytscha. Dis Aquat Org 38:75-79

Meyers TR, Short S, Farrington C, Lipson K, Geiger HJ, Gates R (1993) Establishment of a negative-positive threshold optical density value for the enzyme-linked immunosorbent assay (ELISA) to detect soluble antigen of Renibacterium salmoninarum in Alaskan Pacific salmon. Dis Aquat Org 16:191-197

Monzyk FM, Hoffnagle TL, Carmichael RW, Eddy DL, Keniry PJ (2007) Lower Snake River Compensation Plan: Oregon spring Chinook salmon evaluation studies. 2004 Annual Progress Report, Oregon Department of Fish and Wildlife, Salem, OR

Neter J, Wasserman W, Knuter MH (1990) Applied linear statistical models, 3rd edn. Richard D. Irwin, Homewood, IL

Oregon Department of Fish and Wildlife (2004) Grande Ronde Basin Spring Chinook Salmon Captive Broodstock Program. Bonneville Power Administration project number 1998-01-001. 2003 Annual Report. Oregon Department of Fish and Wildlife, Salem, OR

Oregon Department of Fish and Wildlife (2005) Grande Ronde Basin Spring Chinook Salmon Captive Broodstock Program. Bonneville Power Administration project number 1998-01-001. 2004 Annual Report. Oregon Department of Fish and Wildlife, Salem, OR

Oregon Department of Fish and Wildlife (2006) Grande Ronde Basin Spring Chinook Salmon Captive Broodstock Program. Bonneville Power Administration project number 1998-01-001. 2005 Annual Report. Oregon Department of Fish and Wildlife, Salem, OR

Oregon Department of Fish and Wildlife (2007) Grande Ronde Basin Spring Chinook Salmon Captive Broodstock Program. Bonneville Power Administration project number 1998-01-001. 2006 Annual Report. Oregon Department of Fish and Wildlife, Salem, OR

Pascho RJ, Elliott DG, Streuffert JM (1991) Broodstock segregation of spring chinook salmon Oncorhynchus tshawytscha by use of the enzyme-linked immunosorbent assay (ELISA) and the fluorescent antibody technique

Editorial responsibility: Mark Crane,

Geelong, Victoria, Australia
(FAT) affects the prevalence and levels of Renibacterium salmoninarum infection in progeny. Dis Aquat Org 12: $25-40$

Pascho RJ, Goodrich TD, McKibben CL (1997) Evaluation by enzyme-linked immunosorbent assay (ELISA) of Renibacterium salmoninarum bacterins affected by persistence of bacterial antigens. J Aquat Anim Health 9:99-107

Rohovec J (1991) Overview of selected diseases and drug needs for Salmonids. Vet Hum Toxicol 33: 24-29

Sokal RR, Rohlf FJ (1995) Biometry, 2nd edn. WH Freeman, New York

Turaga PSD, Wiens GD, Kaattari SL (1987) Bacterial kidney disease: the potential role of soluble protein antigens. J Fish Biol 31(Suppl A):191-194

Waples RS (1999) Dispelling some myths about hatcheries. Fisheries 24:12-21

Wiens GD, Kaattari SL (1989) Monoclonal antibody analysis of common surface proteins of Renibacterium salmoninarum. Fish Path 24:1-7

Wiens GD, Kaattari SL (1999) Bacterial kidney disease (Renibacterium salmoninarum). In: Woo PTK, Bruno DW (eds) Fish diseases and disorders, Vol 3: viral, bacterial, and fungal infections. CABI Publishing, New York, p 269-301

Wilson WH, Ruzycki JR, Carmichael RW, Onjukka S, Claire G, Seals J (2002a) Fish Research Project Oregon. John Day Basin spring chinook salmon escapement and productivity monitoring. Annual progress report 2000-2001. Prepared for Bonneville Power Administration, Portland, Oregon. Oregon Department of Fish and Wildlife, Salem, OR

Wilson WH, Ruzycki JR, Carmichael RW, Onjukka S, Claire G, Seals J (2002b) Fish Research Project Oregon. John Day Basin spring chinook salmon escapement and productivity monitoring. Annual progress report 2001-2002. Prepared for Bonneville Power Administration, Portland, Oregon. Oregon Department of Fish and Wildlife, Salem, OR

Submitted: October 4, 2006; Accepted: June 11, 2007

Proofs received from author(s): August 16, 2007 